\title{
Rural E-commerce Two-way Logistics Model Design*
}

\author{
Lijun Fan \\ School of Management \\ Harbin Normal University \\ Harbin, China
}

\author{
Li Sun \\ School of Economics \\ Shandong University of Finance and Economics \\ Jinan, China
}

\begin{abstract}
Agriculture is a key problem for China's political and economic development. There is mismatching between the demand and supply in the development of agricultural economy. In the process of necessities downlink and the agricultural products going up, there are structural contradictions in the supply and demand of product quantity and quality and logistics facilities. The agricultural supply side reform is imminent. Based on the analysis of farmers living supplies and sales of agricultural products, the paper evaluates the lack of existing rural traditional commercial and e-commerce model. In the design of two-way logistics operation mode of the rural e-commerce, it collected the farmers, village stores, distributors; logistics companies, financial institutions and government, and integrate the arrangement of resources and demand. It arranges the distribution and production activities in the overall computing platform.
\end{abstract}

Keywords-agriculture supply-side structural reform; rural ecommerce model; two-way logistics

\section{INTRODUCTION}

Agriculture is the lifeblood of economic development. Agriculture is also an important part of China's continuous tide of supply-side structural reform. At this stage, the major problems existing in the systems of agricultural production and management and peasants' living expenses have not only been the shortage of aggregate quantities, the structural contradictions that coexist in phases of over-supply and undersupply have become the main contradictions of the rural economy under the new normal economic conditions. "Promoting Agricultural Supply-side Structural Reform" became a highlight and innovation in 2016 Document No.1.

The construction of a new type of agricultural management and commercial system is to meet the requirements of agricultural supply-side structural reform. In this process, while supporting a new type of subject, we can't neglect the important status and role of family management in agricultural production and operation. At this stage, the family business of peasant households is no longer a traditional and purely small peasant economy. The products are not only self-sufficient, but also of a higher degree of marketization. The trend of organization among farmers is obvious. The modern farming

*Fund Project: Ministry of Education Humanities and Social Science Project (15YJA790052), Harbin Normal University deepening education and teaching reform project (111-120400156), Shandong Province Social Science Planning Research Project (17CJJJ26). methods and concepts, technologies, facilities and management have all been introduced to a certain extent. Social division of labor tends to be fine. Many production processes allow transition to social service organizations to promote large-scale production. Due to the fragmentation of the family business and the restriction of rural logistics and other factors, the modernization of agricultural production, management and rural household life has been hampered. Innovative models of agricultural production and sales can play a huge role in promoting supply-side reforms in agriculture.

The development of rural e-commerce has provided the necessary material and technical conditions for the realization of the above objectives. The existing rural e-commerce platform is committed to using advanced computer systems and information network technology to produce and sell agricultural products as the mainstay to promote rural production management, online marketing of agricultural products, logistics management. Rural e-commerce has set up a bridge for the exchange of information and materials in rural areas and cities, providing the conditions for the upside of agricultural products and the downside of living goods. The establishment, operation and optimization of the new mode of production and operation take a long time. However, due to the restriction of rural market geographical location, traffic conditions, logistics outlets, farmer education level and distribution networks, the "last mile" obstacle appeared in the development of rural e-commerce. How to effectively integrate existing resources and establish a modern, networked and highly efficient rural e-commerce model are the starting points for the reform of the agricultural supply-side and an important link in raising peasants' income and improving the quality of life. Through the evaluation of the traditional rural logistics model, it is found that the traditional decentralized distribution and logistics mode hinder the efficiency of the e-commerce transaction. It is necessary to analyze the interrelationship between the existing resources related to rural electricity suppliers and the rural electricity supplier based on the idea of agricultural supply-side structural reform, the concept of resource integration and systematic thinking, to build a multilevel, multi-center, complex logistics network support rural electricity supplier model. 


\section{THEORY AND REFERENCE REVIEW}

Logistics is the most important part of the development of e-commerce and an important part of the e-commerce system to improve operational efficiency. Rural logistics refers to the integration of the rural areas from material procurement to the formation of agricultural products, the various activities from the storage, distribution and processing of agricultural products to the sale of rural residents in rural areas. Involving living materials and agricultural materials down and agricultural products up two-way logistics system, in today's environment of e-commerce, logistics system and various types of financial innovation in cities, which are extremely rich and rapidly updated, the rural logistics and matching financial services in our country have been developing slowly, unable to adapt to and support the development of rural economy. How to solve the "last mile" in rural areas has become an important issue to be solved urgently. The improvement and solution to this problem must not only be extended by logistics and more extensive coverage, but also require the mutual matching of finance, insurance and social services to establish a modern agricultural e-commerce two-way logistics system.

\section{A. Agricultural Supply Demand Structure}

Supply and demand theory is one of the basic theories of economics, but also the theoretical basis for the implementation of the supply-side structural reforms in our country at this stage, however, the supply-side structural reform in our country is by no means a simple one. The supply school increases investment by increasing investment through policies such as tax cuts to create a "trickle-down effect"(Liu Qi, 2016). The focus of China's economic supply-side reform lies in its structural matching with the demand side. This is even more evident in agriculture. The major problems facing agricultural development and agricultural modernization are not simply the lack of quantity but the technical level of supply and the degree of modernization and demand Structure does not match. China's agricultural production area scattered, poor production and marketing information and logistics lead to the phenomenon of hard to sell and expensive to buy, Behind this is the imbalance of supply and demand of agricultural products, which has also affected the growth of rural economy and the improvement of peasant welfare (Zhan Hui,2016). The objective of the structural reform on the supply side of agriculture is to promote the docking of agricultural supply needs and the shift of production mode.

\section{B. Rural E-commerce and Agricultural Development}

Most developed countries mostly adopt intensive agricultural production and management, whose mechanized use is extensive and the efficiency of agricultural products logistics is relatively high. However, the development of China's agricultural logistics is relatively slow. In recent years, with the continuous development of rural e-commerce, the demand-driven rural logistics system has been gradually improved, and related research has also gradually been enriched. The definition and research of rural logistics involve all logistics-related activities in agricultural production, including a series of activities such as the procurement of agricultural materials such as seeds, the harvesting, storage, processing and sales of agricultural products and the procurement of peasants' living materials (Wang Xinli, 2003). In addition, the construction of rural logistics system relies on the construction of regional logistics infrastructure and information system (Zhao Liming, 2003). Qiu Lingli (2008) and other scholars have further divided rural logistics into agricultural logistics and peasant consumer goods logistics. Liu Dongying (2005) argues that the logistics process of agricultural products is the commodity exchange process of its value added, including business flow, information flow, logistics and capital flow. Agricultural product logistics is the flow of agricultural products from the supply to the final acceptance of the entity, in order to meet customer's needs. In summary, rural logistics includes two directions, agricultural products upside down and living materials down. The study of rural two-way logistics mainly focuses on the traditional mode upgrading under the promotion of e-commerce. From the perspective of "two-way circulation between urban and rural areas", the e-commerce logistics model involved in agricultural products "going to town" and agricultural materials "going to the countryside" are basically integrated. With a view to achieving the purpose of sharing logistics information and distribution channels, the traditional one-way rural logistics operation mode can be broken through (Liu Yaonan et al., 2014). The above qualitative analysis mainly focuses on the simple logistics and the utilization of rural traditional resources, while neglecting the support that the Internet financial services can bring to the rural e-business model under the support of information modernization and big data.

\section{Rural E-commerce Support Elements}

The development of internet finance has provided broader support and innovation drive for the development of rural ecommerce. While it promoted financial innovation and ecommerce, it also provided a more convenient way for the implementation of GSP in rural areas. In many rural areas, we have set up one after another financial service stations integrating financial services, e-commerce, logistics services, basic medical services and other functions. However, at present, rural e-commerce is still in the initial stage of business development (Gao Sheng, 2015). The profitability of the ecommerce platform is not enough, and the economic benefits are not obvious. It is difficult for financial institutions to find a suitable profit model in the short term (Lin Jie, 2015). The initial cost of operating the site is relatively large; maintenance technology of the platform development is relatively backward. At present, the support of rural e-commerce by internet finance is mainly concentrated on the third-party payment and freight insurance, and the combination with logistics system and the promotion of small and micro loans are still at the low level. Most banks operate in conjunction with third-party providers (Liu Xiaofen and Chen Yong et al., 2014). How to give full play to the role of financial resources in allocating resources and finding the right mode of operation is the key to the grafting of financial institutions and rural markets. 


\section{CURRENT SituATION OF RURAL E-COMMERCE IN CHINA}

One of the main reasons why e-commerce is accepted and rapidly developed by the public is the saving of transaction costs. However, the restriction of rural logistics and the lack of e-commerce services for agricultural products increase the transaction costs, making the advantages of e-commerce relative to traditional transactions disappear. The low degree of informatization of village and village logistics in our country increases the information cost and search cost in circulation. However, the chaos of management and planning of rural logistics distribution system leads to the increase of decisionmaking costs and bargaining costs. The dispersion of logistics and distribution links and logistics technology behind will cause a variety of transaction costs increase. One of the key points of agricultural supply-side structural reform is cost reduction, which is a prerequisite for lowering inventories. The establishment of a rational and scientific two-way rural logistics system is conducive to reducing the transportation and circulation links. Logistics system grafting financial tools and social security system will co-ordinate resources and reduce transaction costs to a greater extent.

\section{A. The Basic Size}

With the increasing popularity of Internet technology and the continuous expansion of various e-commerce platforms, a series of e-commerce sites have been set up in rural areas of our country. Rural e-commerce has taken initial development. Farmers in many economically developed regions have achieved Internet transactions Sales of agricultural products to expand and profit. Through the network's propaganda role, there are many successful cases that help farmers solve the problem of unsalable products. Based on the obvious superiority of rural electricity suppliers, the government has also issued a number of supportive policies and guidance to support the construction of agricultural products circulation, warehousing, marketing networks, e-commerce platforms and informationization 1. The policy is in good condition. In terms of overall scale, the market size of rural online shopping in 2015 was 353 billion Yuan, up to 482.3 billion Yuan in 2016, an increase of $36.6 \%$ over the same period of previous year, making it a new growth point for the retail e-commerce market2.

\section{B. Low Prevalence of Internet Applications}

Internet technology is an essential factor for the development of e-commerce. Internet-based e-commerce platform is the core of rural e-commerce operations; platform operating mode determines the function of e-commerce system, profitability and ability, the level of efficiency. In terms of

The relevant policies include "Guiding Opinions on Promoting Adequate Scale Operation of Agriculture in Comprehensive Development of Agriculture" (2015), "Guiding Opinions on Comprehensive Agricultural Development to Support Advantages and Disadvantages of Agriculture in Promoting Agricultural Industrialization" (2015), "Guidelines on Promoting Agricultural and Rural Big Data Development Implementation Opinions "(2016), "Agricultural E-Commerce Pilot Program"(2016) and so on.

Source: 2016 Data Monitoring Report on China's Online Retail Market, China E-Commerce Research Center quantity, the construction of rural e-commerce platform in China has accelerated in recent years, and the number of ecommerce platforms has rapidly risen. Among these, the expansion of large-scale e-commerce platforms to the rural market and the construction of self-built platforms in rural areas are also included. However, in terms of the innovation and sustainability of platform operation mode, rural ecommerce in our country is still in its infancy, which still lags behind the city's e-commerce platform.

As the gap between urban and rural areas of the Internet penetration rate is still significant, as of June 2016, the Internet penetration rate in rural areas was only $31.7 \%$ and that in urban areas exceeded that in rural areas by 35.6 percentage points. The level of education and traditional farming ideas affect many farmers' ideology and learning ability. In addition to the backwardness of hardware facilities, due to the obstacles of using network end users caused by "not going online" and "not wanting to surf the internet", it is still the main reason why ebusiness models are difficult to promote in rural areas. $68 \%$ of rural non-Internet users do not surf the Internet because they "do not know computers or the Internet" and the proportion of rural non-Internet users who consider "unnecessary or not interested" is $10.9 \% 3$.

\section{Low End Logistics Coverage and Resource Sharing}

Our country is a big agricultural country. From the point of view of the land area, the rural areas are widely distributed, and a large number of rural areas are located in remote areas with relatively backward transportation. This is the crux of the hardto-solve "last mile" problem. Most of the distribution of logistics enterprises end range only to the township, rural areas below the township logistics difficult to reach. Most of the distribution of logistics enterprises ends only to the range of township. Rural areas below the township logistics are difficult to reach. The problem of "end logistics" makes the demand of e-commerce in rural areas unsatisfied, and the agricultural products produced by the same peasants can hardly be delivered to consumers in time. In the traditional logistics system, the distributors of products are mostly responsible for the transportation of their own products and can't share resources. Therefore, in order to obtain the development of rural e-commerce, we must establish a sound logistics system to solve the "end logistics" and logistics resources sharing.

\section{Internet Finance Provides Conditions for Development of Universal E-commerce in Rural Areas}

GSP finance is a key issue in financial development and 'three rural issues' in recent years. However, in many backward areas, financial institutions and facilities are still relatively scarce, their basic financial needs are not met, and they still remain in the basic deposits and a small part of the loan business carried out by rural credit cooperatives and mutual aid organizations. The development and popularization of internet finance has provided new conditions for GSP finance. As long as the areas covered by the network can enjoy equal financial services and reduce the resources and costs of network settings

\footnotetext{
Data Source: CNNIC Statistical Survey on the Internet

Development in China 2016
} 
and personnel of financial institutions, it also provides comprehensive financial support for the living and production of farmers.

\section{E. Supply and Demand Analysis of Rural E-commerce Services}

Farmers in our country have multiple identities in the market, first of all, consumers, followed by suppliers of agricultural products, and third, supply of elements as factor owners. As a result, there is more demand than the average city consumer: From the physical demand perspective, it combines the demand for living supplies as a consumer; as a demand for agricultural products suppliers for the production of materials and raw materials. From the service demand perspective, it includes personal service needs as consumer business, travel, education, safety and health, postal communication, computer and finance; as a service provider for business announcements, judiciary, security, registration and other services. At present, the degree of satisfaction of these needs is only in the initial stage, a large number of demands can't be met. The supply of commodity supplies is also limited to all brand dealers go it alone. Information services have serious lag, basic services can't benefit the village. The cost of laying physical outlets and the transaction costs with scattered farmers are all higher, further hindering the matching between supply and demand. The most cost-effective solution to this problem lies in effective resource integration of existing dealers, village shops, logistics enterprises, e-commerce platforms, financial institutions and government services under the new rules and models.

TABLE I. DEMAND ANALYSIS OF RURAL E-COMMERCE SERVICES

\begin{tabular}{|c|c|c|}
\hline Service type & \multicolumn{2}{|c|}{ Rural e-commerce service needs } \\
\hline \multirow{2}{*}{ Personal service } & $\begin{array}{l}\text { Business } \\
\text { needs }\end{array}$ & Travel demand \\
\hline & $\begin{array}{l}\text { Education } \\
\text { needs }\end{array}$ & Health demand \\
\hline \multirow{3}{*}{$\begin{array}{l}\text { Information } \\
\text { service }\end{array}$} & $\begin{array}{l}\text { Business } \\
\text { bulletin needs }\end{array}$ & Security service information \\
\hline & $\begin{array}{l}\text { Judicial } \\
\text { service needs }\end{array}$ & Health service information \\
\hline & $\begin{array}{l}\text { Registration } \\
\text { information }\end{array}$ & $\begin{array}{l}\text { Educational } \\
\text { Information }\end{array}$ \\
\hline \multirow[b]{2}{*}{ Basic services } & Postal service & Communication services \\
\hline & $\begin{array}{l}\text { Computer } \\
\text { service }\end{array}$ & Financial Services \\
\hline
\end{tabular}

\section{RURAL E-COMMERCE "TwO-WAY LOGISTICS" MODEL} DESIGN

\section{A. The Basic Idea}

Based on the types of demand in the production and living of peasants at this stage, the new rural e-commerce model must first reflect the dual needs of peasants, the demand of ordinary consumers for living and means of production, and their willingness to sell as producers of agricultural products. Second, to achieve the effective integration of existing distributors and logistics resources, to achieve the last mile of effective material transport, we must also integrate decentralized sources of agricultural products at the same time. Third, there is a need to achieve an effective and organic integration of modern financial and security systems, while providing financial guarantees for rural e-commerce transactions and at the same time improving the level of protection and reducing the losses of farmers. Fourth, improve the maneuverability of e-commerce equipment terminals and reduce the learning costs of farmers. Based on the realization of these four goals, we try to grasp the demand information of regional agricultural products through the analysis of platform big data, and guide farmers' production and processing of agricultural products in quantity, quality and personalization.

\section{B. Basic Elements and Functions}

The basic elements involved in the "two-way logistics" model of rural e-commerce include farmers, urban consumers, e-commerce platforms, FMCG and agricultural product distributors, third-party logistics enterprises, financial and insurance companies, social services and guarantee agencies.

Farmers are the core and terminal of rural e-commerce logistics system. Under the dual identities of consumers and producers of agricultural products, their needs also include the needs of consumer goods and agricultural products and the demand for the cultivation and sale of agricultural products. In addition, based on the status quo of rural population outflows, the uneven knowledge structure and the slow acceptance of new things, the new rural E-commerce model should pay attention to the integration with the traditional commodity transaction mode in the design of the client and interaction mode, as well as the convenience and easy to learn client operating mode.

E-commerce platform is the core of the entire rural ecommerce system. From the perspective of the operation mode, the platform needs to serve as the basic function of integrating related resources and designing the cooperation mode of all parties involved in the grafting of functions and distribution of benefits. From the perspective of software and hardware support, the design of the support system and port of each platform and the data processing and utilization are the necessary support for the operation of rural E-commerce system and also the core influencing factors of operational efficiency.

FMCG and agricultural machinery product distributors, third-party logistics companies, financial and insurance 
companies, social services and security agencies are the elements that need to be effectively grafted and integrated in the new rural e-commerce model. Among them, the distributor has the traditional marketing model of product channels and part of the self-employed logistics resources. However, their own mode of marketing makes its resource utilization less efficient. Logistics enterprises cannot cover the majority of villages because of the cost of laying outlets. Even in economically developed areas, most logistics enterprises can only be deployed to outlets at the township level, failing to provide door-to-door delivery services. Financial and insurance enterprises also face the difficult problems in rural areas. The high cost of physical outlets and the lack of credit system for farmers make that the realization of GSP financial needs the help of the Internet. Various services in the Internet and the last mile progress in the long move will cause waste of resources and service terminals of the complexity of diversification, resulting in operational difficulties. Therefore, it's significant to effectively integrate the above elements.

\section{Two-way Circulation Model Design}

According to the basic design concept of rural e-commerce, the process is divided into the downstream of production materials and daily necessities and the upturn of agricultural products. In the process of agricultural product up-going, there are also $\mathrm{C} 2 \mathrm{C}$ (Business to Consumer) models for urban consumers such as $\mathrm{C} 2 \mathrm{C}$ (Consumer to Consumer) model of urban consumers directly, large-scale planting farms or rural cooperatives, C2B (Consumer to Business) model. Although they are different modes of circulation, they all can be implemented through the same system. Now according to the specific mode of operation, the design of the corresponding process is as follows:

1) Basic production supplies and daily necessities down going: As the primary function of rural e-commerce, we should ensure that the basic production and living materials are effectively traded and transported to households. In this mode, the dealer network needs to be integrated. According to the demand information collected by each village store in a certain area, the overall planning is to allocate the warehouses and logistics routes for the products. The specific operation modes and processes are shown in "Fig. 2".

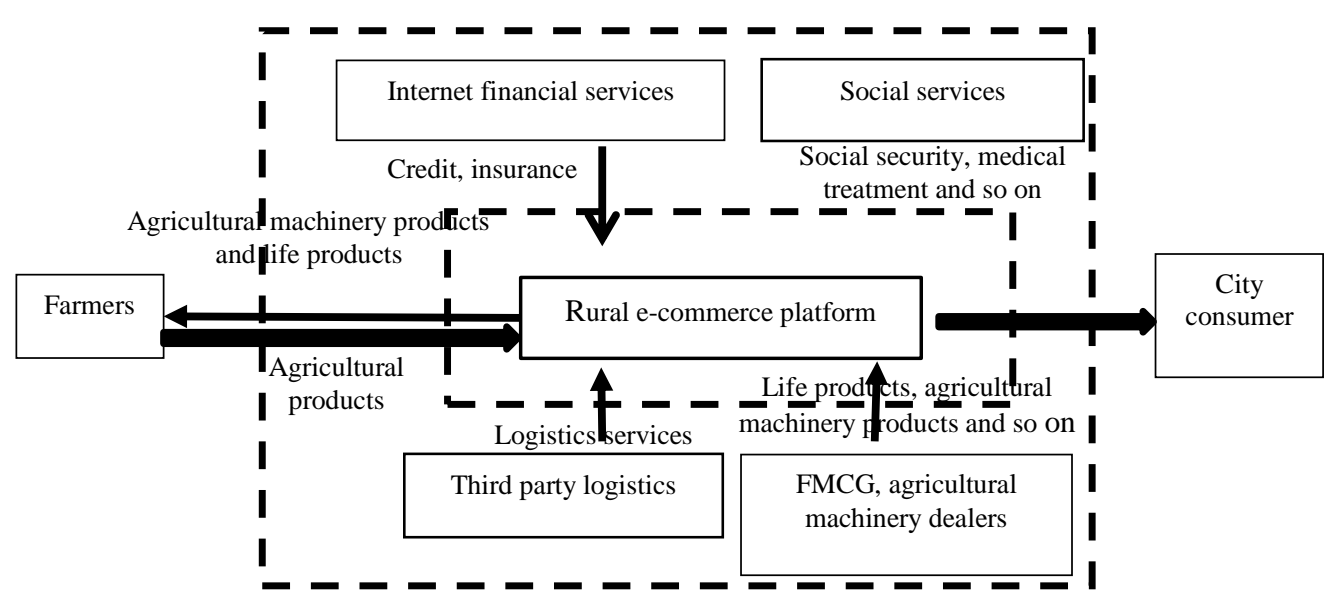

Fig. 1. The basic idea of a new model of rural e-commerce. 


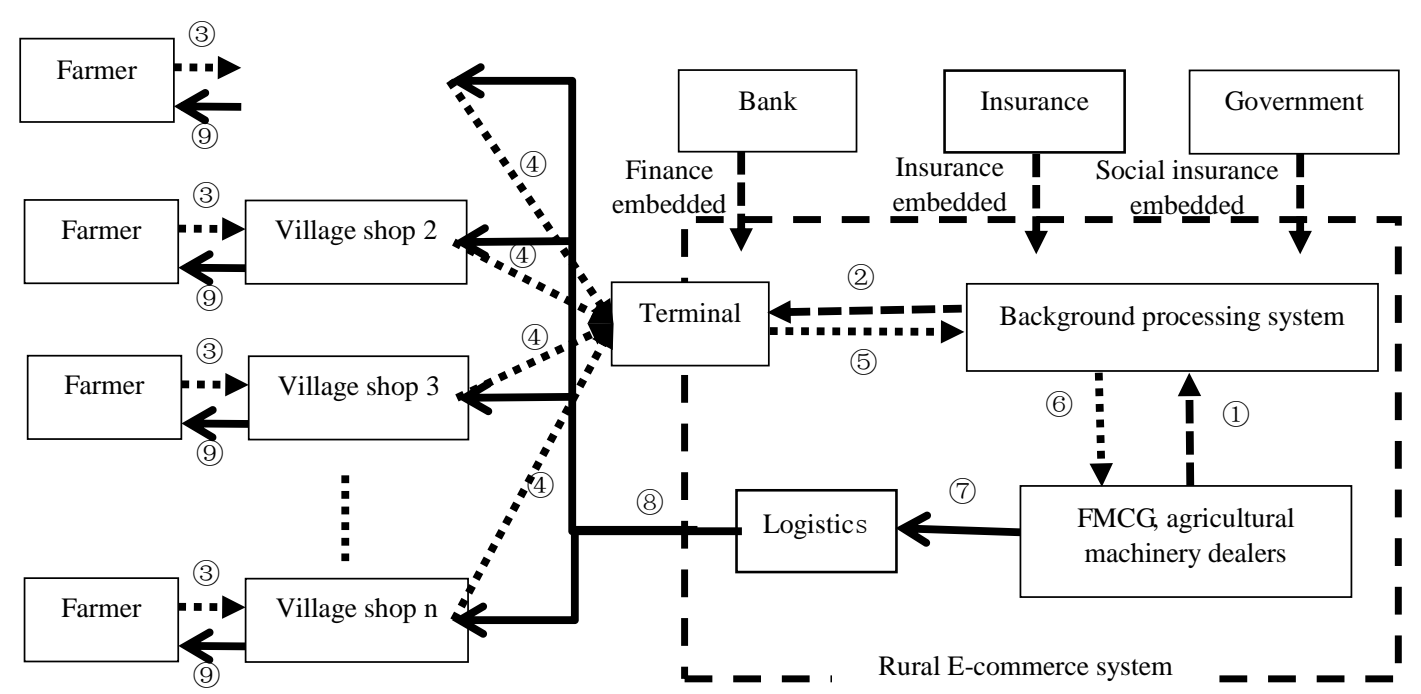

a. (1) Product information entry (2) Commodity information summarized transmission, terminal display (3) demand information communication (4) demand information summarized into the terminal (5) information transfer summary processing integration (6) demand information distribution and convey to the dealer (7) overall arrangements for distribution routes and distribution tasks (8) commodity delivered to the village shop and delivery notice delivered to the farmers (9) farmer pick-up or village point delivery

Fig. 2. Production supplies and daily necessities downward business model.

2) $C 2 C$ and $B 2 C$ modes: The $\mathrm{C} 2 \mathrm{C}$ model refers to the model of rural households directly to urban consumers, while the B2C model refers to the model of urban consumers such as large-scale planting farms or rural cooperatives. These two modes are a pattern of agricultural upside, characterized by each farmer as a supplier of agricultural and sideline products, according to the characteristics of their products separately participate in the operation of e-commerce platform, due to the large number of farmers, personalized obvious product differentiation exists. So the role of e-commerce platform is to provide information release and matching, and to assist the transport of goods. Specific operational flow chart is shown in "Fig. 3".

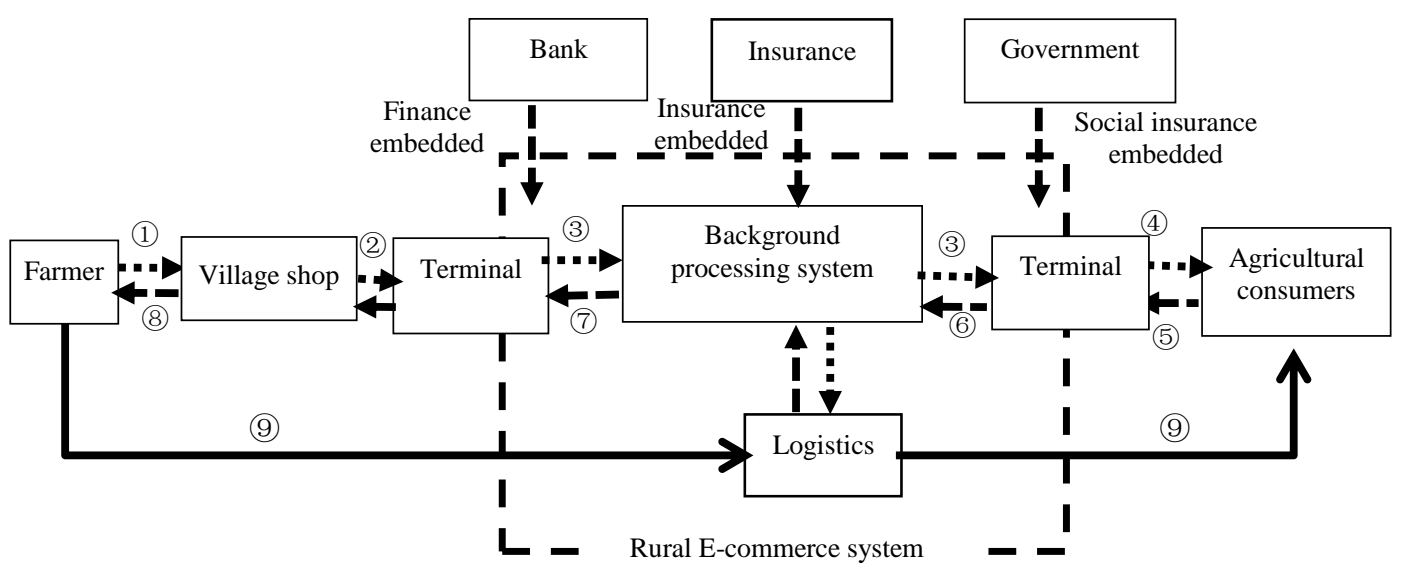

b. (1) Farmers' agricultural products summary (farm or cooperative product summary) (2) agricultural product information entry (3) agricultural information terminal display and convey to the consumer (4) demand information input terminal (5) transport summary processing integration demand information (6) issue demand information (7) demand information transfer, farmers take orders, prepare the goods (8) agricultural products stocking and issue logistics tasks (9) logistics and distribution

Fig. 3. Agricultural products upstream business model one (C2C or B2C).

3) Farmers' C2B mode to agricultural products wholesalers (pre-order mode): In the agricultural product reservation mode, the farmers produce according to the preorder. Under the new operating mode, due to the embedding 
of finance, insurance and social security, the loan can be provided as guarantee for the farmers and the insurance can be provided for the production. After the order is completed, the purchase price is also given priority to repay the loan under the control of the rural e-commerce platform, providing funds for the production of farmers while also ensuring the effective transfer of loan-able funds and loan recovery of the financial system. At the same time, the embedding of insurance and social security also guarantees the production risk and the default risk. The specific mode of operation and flow chart is shown in "Fig. 4".

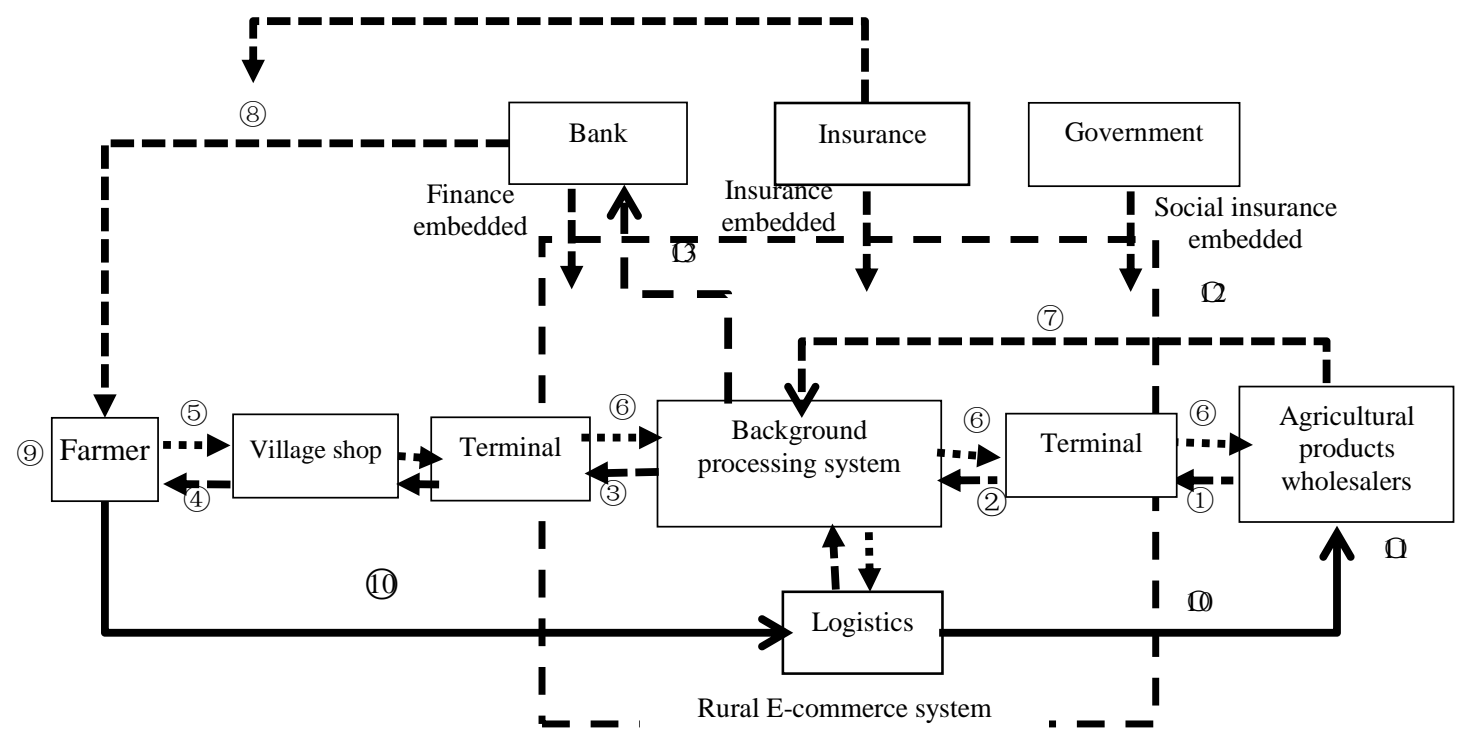
c. (1) agricultural products wholesalers release agricultural demand information (2) information transfer, match the origin (3) display the demand information on the terminal of the village shop after information
processing (4) farmers search demand information (5) farmers take orders (6) information transfer (7) pay product margin (8) give special loans, insurance according to the case of farmers (9) farmers carry out production (10) logistics and distribution (11) inspection (12) confirm the receipt and pay the balance (13) first pay bank loans, the final payment into the individual accounts of farmers

Fig. 4. Agricultural products upstream business model two (Pre-order Mode).

The core of the above model lies in the effective integration of suppliers, logistics, financial insurance and social security resources. Whether through the rural ecommerce platform for terminal data aggregation and calculation, to arrange the best product delivery routes; or the embedding of financial services, all these effectively solve the problems of the lack of collateral of small and micro loans, the lack of credit and the difficulty of payment. As well as life products down going and agricultural products up going share resources and avoid the problem of empty cargoes, all fully reflect the effective integration of existing resources.

\section{POLICY SUPPORT}

Market-oriented operation provides the mature experience of urban e-commerce and private capital support for the development of rural e-commerce. At the same time policy support is also essential.

First, strengthen the construction of rural network infrastructure and the promotion of Internet applications. The popularization of Internet infrastructure provides an effective channel for information transmission, and also provides convenient conditions for the universal benefits of finance and social security. However, there are still serious urbanrural differences in the popularization and application of the Internet. Therefore, we should extensively promote the construction of rural network infrastructure, especially the wireless network, and ensure the instant access of mobile communication terminals.

Second, improve the level of education of peasants and strengthen the education and training of e-commerce. The progress of carrying out rural e-commerce business is closely related to the level of education and training of peasant households. The superiority of e-commerce must be widely publicized and the education and training of rural ecommerce personnel should be strengthened. We can carry out related lectures and ask professionals to explain various business processes of e-commerce, to teach peasant households how to use computers and mobile terminals to use the Internet, how to use the network platform to sell agricultural products, how to conduct transactions through the Internet, and online settlement.

Third, formulate a special industrial plan and establish a sense of place of origin. A characteristic agricultural product is the entry point for agricultural products to go up in the development of rural e-commerce. Therefore, the planning of special industries and guide the cultivation of agricultural products, production and processing, to help farmers and cooperatives to establish a sense of origin, registered trademarks of origin, while promoting production and income, it can also safeguard the quality of products and eliminate fake and shoddy products to disrupt the market. 
Fourth, continue to promote and improve rural infrastructure construction. The construction of rural infrastructure such as warehousing and logistics facilities and irrigation and water conservancy facilities is the basic guarantee for the development of agriculture and rural economy and life improvement and also the basis for the development of rural e-commerce. Increasing the construction of important agricultural products warehouse logistics facilities, providing a unified warehousing and logistics services for different brands of different levels of dealers ,integrating supply, will largely reduce costs and improve efficiency.

Fifth, promote the embedded docking of social security and third-party services; improve the relevant state laws and regulations. Pension, medical and productive financial services and insurance services are the necessary guarantees for farmers to carry out agricultural production. How to establish a good docking and embedding with its rural ecommerce platform is the basis for guaranteeing the integration and modernization of rural e-commerce. The state should guide and promote policies and industry rules and regulations. On the basis of establishing and improving legal and financial policies in the financial market, increase market supervision, crack down on counterfeit and shoddy products, and promote the long-term healthy development of rural e-commerce.

\section{CONCLUSION}

Agriculture is an important part of China's reform of the supply-side structure. Building a new type of agricultural management and business system requires innovative agricultural production and marketing models for the structural reform of the supply side of agriculture. Rural ecommerce as a platform to build multilevel, multi-center, complex, scientific rural two-way logistics network system, grafting of financial instruments and social security systems, coupled with the support of government, resources will be more comprehensively coordinated, transaction costs will be reduced, the logistics of agricultural products will be reduced, and supply-side integration of daily necessities and agricultural products can be realized.

\section{REFERENCES}

[1] Gao Sheng. Research on the Development of Rural E-commerce Logistics in China Based on Long Tail Theory [J]. China Storage \& Transport, 2015 (7): 124-126.

[2] Wang Pingchun, LIN Jie.Study on the Development Strategy of Luzhou Liquor Business E-commerce [J]. Nanfang Agricultural Machinery, 2015 (4): 16-18

[3] Chen Yong, Liuxiao Fen, Li Bosheng. Research on Correlation between E-commerce Financial Credit and the Development of Ecommerce Micro-enterprises - Analysis of Ali's Financial Credit Information Model and Its Enlightenment [J] Fujian Finance, 2014 (12): 62-66.

[4] Nie Linhai. Characteristics and Trends of E-commerce Development in China [J]. China Business and Market, 2014 (6): 97-101

[5] Lin Jie. Study on the Current Situation of Rural E-commerce [J] .Nanfang Agricultural Machinery, 2015 (1): 94-95.
[6] Gong Yongqin. Internet helps China's financial development of inclusiveness [J]. Journal of Beijing Vocational College of Labour and Social Security, 2015, 9 (1): 42-46.

[7] Zhang Yuzhe. E-commerce enters into rural finance $[\mathrm{J}]$.Caixin Century, 2015 (8): 40-43.

[8] Ma Jiujie. Financial Innovation Driven by Agricultural Modernization and Rural Financial System Reform [J] .Agricultural Development and Finance, 2015 (03): 20-22.

[9] Han Jingqi. E-commerce platform, the last stop of China Unicom's rural finance [J]. China Rural Finance, 2015 (15): 32-33.

[10] Zhang Chi. Survey of Rural E-Commerce Patterns in China of 2015[N]. China Times for Cooperation, 2015-10-23 (A07).

[11] Jin Xiaoyan, Miao Dezhi. Rural Financial Services: A Study on the Model of "Finance - E-commerce" [J]. Financial Regulatory Research, 2015 (08): 68-81.

[12] Sun Hua.Construction of integrated rural e-commerce model based on cloud computing [J] .Agricultural Economy, 2017 (03): 127-129. 